The Drosophila DNA in the junction fragments can then be amplified specifically with PCR using primers homologous to the vector sequences situated with their $3^{\prime}$ ends flanking the Drosophila insert in the circularized molecules ${ }^{13}$. The length of Drosophila DNA in the circularized junction fragments is determined by the position of the closest EcoRV or HincII site. We determined the expected size of the probes resulting from inverse PCR from Southern blots of yeast genomic DNA using the same restriction enzymes used to generate the junction fragments. Probes specific to the junction nearest the centromere can also be obtained by plasmid rescue $^{3}$

Probes derived from the junctions of Drosophila DNA inserted into YACs have several uses in mapping. In situ hybridization allows the inserts to be oriented within the Drosophila genome, and their end points to be determined cytologically. (It also reveals which probes contain sequences that are unique in the genome.) Probing Southern blots allows overlaps between YAC inserts to be identified at the molecular level, and probing the entire YAC library allows chromosome walking by identifying additional overlapping clones.

We have identified and linked sets of clones derived from the $83 \mathrm{C}-84 \mathrm{~B}$ region of the salivary gland map (Fig. 1). Additional YACs are being sought to fill in the gaps. Restriction maps of the YACs are presently being determined to establish colinearity with $\lambda$ clones from the region and to confirm the overlaps.

Dan Garza, James W. Ajioka, John P. Carulli, Robert W. Jones and Daniel L. Hartl are at the Department of Genetics, Washington University School of Medicine, St. Louis, Missouri 63110-1095, USA. Daniel H. Johnson is at the Department of Biochemistry and Molecular Biology, University of Miami School of Medicine, Miami, Florida 33136, USA. The authors thank Andy Link for contributing YAC clones to the libraries and Ann Vellek for technical assistance. For more information, fill in reader service number 100

1. Saiki, R.K. et al. Science 239, 487-491 (1988)

2. Johnson, D.H. Genomics (submitted).

3. Burke, D.T., Carle, G.F. \& Olson, M.V. Science 236, 806812 (1987).

4. Ochman, H., Gerber, A.S. \& HartI, D.L. Genetics 120 621-623 (1988)

5. Bender, W., Spierer, P. \& Hogness, D.S. J. mol. Biol. 168, 17-34 (1983)

6. Ochman, H., Ajioka, J.W., Garza, D. \& Hartl, D.L. in PCR Technology (ed. Erlich, H.) (Stockton, New York, in the press).

7. Ajioka, J.W. et al. in UCLA Symp. Mol. Cell. Biol. (eds Clegg, M. \& O'Brien, S.) 122 (Alan R. Liss, New York, in the press).

8. Rasch, E.M., Barr, H.J. \& Rasch, R.W. Chromosoma 33 , 1-18 (1971)

9. Lefevre, G., Jr. in The Genetics and Biology of Drosophila Vol. 1a (eds Ashburner, M. \& Novitski, E.) 31-66 (Academic, New York, 1976)

10. Coulson. A., Waterston, R., Kiff, J., Sulston, J. \& Kohara Y. Nature 335, 184-186 (1988).

11. Scott, M.P. et al. Cell 35, 763-776 (1983)

12. Lindsley, D.L. et at. Genetics 71, 157-184 (1972),

13. Ochman, H., Medhora, M.M., Garza, D. \& Hartl, D.L. in PCR Protocols and Applications: A Laboratory Manual (ed. Innis, M. et al.) (Academic. New York, in the press).

\title{
New tech in biotech
}

New biotechnology products will be exhibited at next week's Congress for Developmental Biologists in Utrecht, the Netherlands.

THE Koch-Light division of New Brunswick Scientific Ltd, exhibiting on stands 27 and 28 , has a Taq polymerase enzyme for DNA sequencing by the dideoxy method (Reader Service No. 101). KochLight's Taq-Seq enzyme is a thermostable DNA polymerase that retains high activity even when DNA sequencing is performed at high temperatures. The company also offers Taq-Syn, a grade of Taq polymerase suitable for standard DNA polymerase reactions. Both Taq-Seq and Taq-Syn are $£ 50$ (UK) for 100 units.

For the sterile filtration of tissue culture media and other biological solutions,

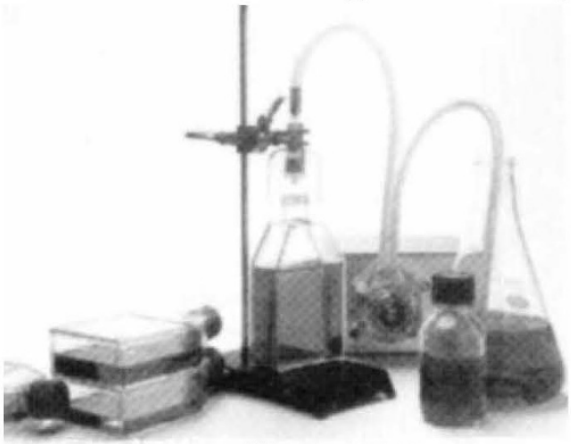

Millipore's Sterivex filter in action.

Millipore, exhibiting on stand 1, offers two new Sterivex Filter Units (Reader Service No. 102). Sterivex filters are now available with pore sizes of 0.22 and $0.45 \mu \mathrm{m}$, with low-protein binding, lowextractable Durapore membranes. The membrane is biocompatible with cell cultures and gives up to 99 per cent protein recovery, says Millipore. Millipore supplies the filter units with or without a filling bell attachment, and with either Luer slip or Luer lock outlets.

Diagen $\mathrm{GmbH}$, exhibiting on stand 9, has a series of kits for plasmid preparation (Reader Service No. 103). Using the Qiagen minipreparation kit, up to 12 preps - each producing up to $10 \mu \mathrm{g}$ of plasmid DNA - can be directly isolated and purified from cell lysates in less than an hour, says the company. The $\$ 93$ (US) kit comes with protocol, Qiagen-tip 20 prepacked pipette tips, and the necessary buffers and solutions to perform 25 preparations.

These notes are compiled by Diane Gershon from information provided by the manufacturers. To obtain further details about these products, use the reader service card bound inside the journal. Prices quoted are sometimes nominal, and apply only within the country indicated.
Kits for in situ mRNA hybridization using radioactive- and nonradioactivelabelled probes are now available from $\mathrm{Du}$ Pont's "NEN" Research Products division (Reader Service No. 104). Tissue or organ sections, or blood or body fluids can be hybridized in situ to either radioactive ${ }^{35} \mathrm{~S}$-labelled probes, or nonradioactive alkaline phosphatase-labelled probes that yield a colorimetric reaction. Nonradioactive-labelled probes with other enzyme or fluorescent tags can be custom-synthesized on request. DuPont says the systems provide a rapid means of detecting oncogenes, infectious disease agents, neurotransmitters, receptors, cell growth regulators, G-proteins and controls. Each $\$ 350-400$ (US) kit contains enough reagents to process 100 tissue sections. Du Pont will be exhibiting on stand 12 .

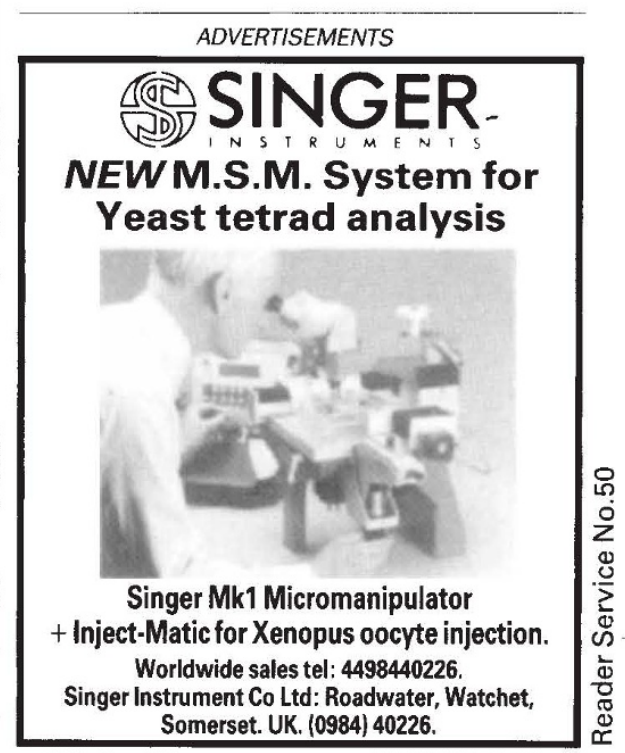

\section{LIPOSOMES}

REPRODUCIBLE - HOMOGENEOUS EXTREMELY RAPID

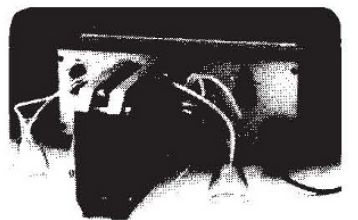

Our new LIPOSOMAT guarantees rapid $(5 \mathrm{ml}$ within 60 minutes) preparation of uniformly sized unilamellar liposomes. Liposome size is selectable between 25 and ca. $600 \mathrm{~nm}$ diameter. Sample volume is normally $5-10 \mathrm{ml}$ or up to $200 \mathrm{ml}$ if used in combination with an additional instrument. Lipid concentration can be up to $300 \mathrm{mg} / \mathrm{ml}$.

\section{DianERM}

POB 126, D-8000 Munich 65, FRG

NATURE · VOL $340 \cdot 17$ AUGUST 1989 